\title{
GENDER ASPECTS OF SUFI PRACTICES IN KAZAKHSTAN AND ABROAD
}

\author{
${ }^{1}$ A. Temirbayeva, ${ }^{2} \mathrm{~T}$. Temirbayev, ${ }^{3} \mathrm{~K}$. Tyshkhan, ${ }^{4} \mathrm{R}$. Kamarova
}

\begin{abstract}
Previously, women have played an important role in the development of Sufism. Sufi tradition recognizes the unity of being, regardless of the gender duality of the world. The recognition of this doctrine contributed to the spiritual development of women in Sufism. Sufi women play an important role in tariqah.

The study of the female Sufi experience, as well as the influence that women had on the Sufi worldview and Sufi practice, is not only valuable from a cultural and historical point of view, but also helps to better understand the place and role of women in Muslim society. In this regard, the article is devoted to the role of women in modern Sufi groups in the world and in Kazakhstan. Famous women-Sufis in history, modern female Sufi organizations in the world and participation of women in modern Kazakhstani tariqas will be considered. The aim is to examine Sufi organizations through the prism of female actors. The materials of the article are based on data from open information and academic sources. Also on field research of Sufi groups in Kazakhstan and Turkey from 2016 to the current period.
\end{abstract}

Keywords: Islamic Feminism, Sufi Women, Gender in Sufism, Women's Sufi Organizations, Sufi Feminism.
1,3 L.N. Gumilyov Eurasian National University, NurSultan, Kazakhstan

${ }^{2,4} \mathrm{~N}$. Nazarbayev Center for Development of Interfaith and Intercivilization Dialogue, Nur-Sultan, Kazakhstan

Corresponding Author:

T. Temirbayev, talgat.

temirbayev@gmail.com

Reference to this article:

A. Temirbayeva, T. Temirbayev, K. Tyshkhan, R. Kamarova. Gender Aspects of Sufi Practices in Kazakhstan and Abroad // Adam alemi. - 2021. - No. 4 (90). - P. 142-152.

\section{Қазақстандағы және шетелдегі сопылық тәжірибелердің гендерлік аспектілері}

Аннотация. Әйелдер суфизмнің дамуында бұрыннан маңызды рөл атқарған. Сопылық дәстүр әлемнің гендерлік дуалдыққа қарамастан болмыстың бірлігін мойындайды. Бұл ілімді тану сопылықта әйелдердің рухани дамуына ықпал етті. Тариқаттарда сопылық әйелдер маңызды орын алды.

Сопылық әйелдердің тәжірибесін, сондай-ақ әйелдердің сопылық дүниетаным мен сопылық тәжірибеге тигізетін әсерін зерттеу мәдени және тарихи тұрғыдан құнды болып қана қоймай, мұсылман қоғамындағы әйелдердің орны мен рөлін жақсылап зерттеуге көмектеседі. Осыған орай, мақала әлемдегі және Қазақстандағы заманауи сопылық топтардағы әйелдердің рөліне арналған. Тарихтағы әйгілі сопылық әйелдер, әлемдегі заманауи сопылық әйелдер ұйымдары және қазіргі заманғы қазақстандық тарифтерге әйелдердің қатысуы қарастырылады. Мақаланың мақсаты - сопылық ұйымдарды әйел әрекетінің призмасы арқылы қарастыру. Мақала материалдары ашық ақпараттар мен академиялық дереккөздердің, сондай-ақ авторлардың далалық мәліметтерінен негізделген. 2016 жылдан бастап қазіргі кезеңге дейін Қазақстан мен Түркиядағы сопылық топтардың далалық зерттеулері өткізілді. .

Түйін сөздер: Ислам феминизмі, сопылық әйелдер, сопылық гендер, сопылық әйелдер ұйымдары, сопылық феминизм 


\title{
Гендерные аспекты суфийских практик в Казахстане и за рубежом
}

\begin{abstract}
Аннотация. С самых первых дней женщины играли важную роль в развитии суфизма. Суфийская традиция признает единство бытия, невзирая на гендерную дуальность мира. Признание этой доктрины способствовало духовному развитию женщин в суфизме. Немаловажную роль в тарикатах занимают женщины-суфии.

Изучение женского суфийского опыта, а также того влияния, которое женщины оказывали на суфийское мировоззрение и суфийскую практику, представляется не только ценным с культурно-исторической точки зрения, но и помогает лучше рассмотреть место и роль женщины в мусульманском обществе. В связи с этим статья посвящена роли женщин в современных суфийских группах в мире и в Казахстане. Будут рассмотрены известные в истории женщины-суфии, современные женские суфийские организации в мире и участие женщин в современных казахстанских тарикатах. Цель рассмотреть суфийские организации через призму женского акторства.

Материалы статьи основаны на данных из открытых информационных и академических источников. Также на полевых исследованиях суфийских групп в Казахстане и Турции с 2016 года по текущий период.
\end{abstract}

Ключевые слова: исламский феминизм, женщины-суфии, гендер в суфизме, женские суфийские организации, суфийский феминизм.

\section{Introduction}

XX-XXI centuries have significantly changed the role of women in the world, there have been radical changes in the legal status of women, began to conquer the minds of people are the idea of gender equality. In most countries of the world, women for the first time gained the right to vote, became full participants in political processes. Women got the right not only to vote - but also to be chosen. Today, women are represented in parliaments and governments of all continents.

Today the international community, including organizations such as UN, its specialized agencies - International organization labor, World Health Organization, refer to the issue of the situation women to the number of global. No wonder the international final documents IV UN World Conference on Women (Beijing, 1995) and The UN General Assembly Special Session "Women 2000: Gender Equality, Development and Peace in the 21st Century" (New York, 2000) contain an appeal to the governments of all countries to take measures to eliminate the social and cultural factors of the existence of an unequal position of women.

At the same time, it should be noted that the change in the place and role of women in Kazakh society has been and is happening in close relationship with dramatic changes in the socio-economic, political and cultural life of Kazakhstan at different periods of its history [1, p. 250].

In modern society, religion plays a significant role, and its transformations lead to the emergence of new religious and cultural phenomena, in particular, such as religious feminism. This is not a single movement, its representatives can be active groups or individuals professing some kind of religion (Christian feminism, Jewish feminism, Islamic feminism, etc.). Increasingly, modern feminists are setting tasks related to the status of women in religion in general and in specific religions in particular. Women are striving not only to strengthen their role in the religious community, but also to create theological concepts that explain the possibilities of women's religious teaching and priesthood.

The 20th century, with its social reforms, contributed to a change in the status of women. The range of traditional social roles has expanded, which has led to a change in the position of women and within religious associations. The development of various women's movements, and in particular the feminist movement, contributed to the growing interest of researchers in studying the role and image of women in religion. $[2$, p. 3] Thanks to the research works of Saba Mahmud [3, p. 5], Orit Avishai [4, 
p. 7], we can look at the participation of women in religious practice through the prism of active actors, and learn the opinion of the practitioners themselves. Women independently and consciously choose conservative and orthodox religious practices and this expresses their selfreflection.

In this regard, this article uses an interdisciplinary approach as a methodological basis, as well as a religious analysis. In addition, qualitative methods of sociological research were used: observation and interviews.

\section{Methods}

The methodology of this article is based on the analysis of the current religious situation in modern Kazakhstan, the established spiritual tradition and anthropological researches of the authors. Also, authors used descriptive, historical, hermeneutics and comparative research methods.

\section{Sufi Women in World History}

First, in order to understand the role of female Sufis, it is necessary to turn to the Quran as the primary source. In the early Islamic period, the society was dominated by a paradigm of segregation. As a result, women's access to education, restriction of rights, etc. According to the Quran, a woman and a man are made of one substance. Also, in the Quran, God addresses people "Oh you! who believed», «O, believers! » without gender differences. However, Islamic scholars focus on Surah An-Nisa, which speaks of a man's responsibility for his family [5, p. 248]. From what scientists conclude that the position of men is higher than that of women. At the same time, Western scholars' orientalists believe that each sex has its own specific role, and in some cases, they complement each other. Speaking of mystical experience, we can mention gender equality.

Secondly, biographical collections are sources about the early Sufis. The authors of such collections were most often men. Basically, such collections describe the life stories and mystical experiences of men, but in some you can find brief records about women mystics. Mentions of Sufi women can be found in the works of the founders of the Islamic hagiographic tradition Rumi, Ibn Arabi and others. Such scientists as Abu Nu'ayam, Ansari from Herat, Jami, Sulami, Ibn Javzi, Attar also collected and recorded the genealogy of Sufi teachers. Abu Nu'ayam died in 1038, collected poems, stories and anecdotes about 648 male Sufis and very little information about female Sufis. Abdullah Ansari from Herat died in 1089, he wrote about 2074 Sufis and not a single woman. Jami is the most outstanding personality in Central Asia, 6080 men, 33 women at the end of the book, briefly. Some discrimination and a superficial look can be noted. Sulami died in 1021, wrote about 103 personalities of male Sufis, while writing a book on women (8 personalities). He attempted to collect data on Sufi women even before the formation of Sufi orders as social institutions. Note that historically the first female Sufis were ascetics. Ibn Jawzi died in 1201, collected data on 1000 Sufi personalities, of which 200 are women. Farid ad-Din Attar from Iran supposedly died in 1221, 72 Sufis described one of them - one famous woman - Rabi'a, the founder of the Sufi doctrine of love. Thus, there is a certain ambivalence when considering the role of women in Sufism.

Thirdly, how the representatives of Sufism themselves saw women-Sufis. For example, the Sufi scholar Abu Bakr Kalabadhi died in 990, considered women inferior due to the inability to perform religious practices (fasting, prayer) on certain days, monthly. Another of the mystical scholars, Ali al-Khujwiri (lived in the 11th century), operated on the following arguments for the benefits of marriage (obtaining spiritual sources), the possibility of procreation, reverence and security. The disadvantages of marriage, he called lust, that is, distraction to the body. He also wrote that "in our time it is difficult to find a suitable wife who does not desire excessively and does not demand without reason; Sufism is based on celibacy; marriage proposal entails exchange; in

\section{4 АДАМ ӘЛЕМІ \\ №4 (90) 2021, желтоқсан}


our day all the evil in worldly and religious life is due to women. Shams ad Din Tabrizi (died in the XIII century) he described a virtuous woman and her chastity, he said despite this, the woman will be consumed by lust. He also noted that if Fatima or Aisha were sheikhs, then he lost his faith in the Prophet. The soul has a feminine nature, or moreover, a woman herself has the nature of a soul, consolidates with her, then opposes her. His statements are misogynistic. Also, some scholars noted that only men wear a beard, referring to the words of the Prophet «no beard, no man». Note that in the works of the famous Jalal ad din Rumi, a couple of binary themes about men and women and their spirituality can be distinguished. These include dominance and submission, authority and dependence.

Fourthly, the most famous woman of Sufism, Rabi'a al-Adawiya, died in $185 / 801$. She is considered the founder of the doctrine of love mysticism. Several sources testify to her vital activity. She led an extremely ascetic life of solitude and celibacy. She considered God to be her true bridegroom, but she considered him the only object of desire, love and reverence. She considered even love for her own children an obstacle to serving God. It is known that she entered into verbal duels with her guests, from which she emerged victorious. Her sermons on Sufism were understandable to anyone. There are many legends and stories about her. It is mentioned in the works of al-Jahiz, al-Sarraj, al-Kalabazi, al-Makki, Attar, Aflaki, Jean-Pierre Camus [6, p. 33-36]. She left no work behind her. Biographers recorded her answers to questions from guests and friends, prayers and instructions. Note that Rabi'a al-Adawiya differs from other ascetics in his disinterested love for God, not for the sake of the benefits that he gives to those who ask. The first biographical records about her do not contain miracles, while in later biographies there are supernatural acts and miracles. The personality of Rabi' al-Adawiyya is semi-legendary, stories about her have inspired many Muslim authors to write romantic biographies and became a source of inspiration for films. In addition to Rabi'i al-Adawiyya, the following Sufi women are known: Shams Marchena, Fatima bint ibn al-Mutanna from Cordoba, Fatima Nishapuri, Wife of the Sufi al-Hakim atTirmizi, Sha'wana (crying), married Fedha (joyful), Jahan-Ara, beloved daughter of Shah Jahan, the Mughal emperor of India, Aisha from Damascus, Bib Hayati Kermani, Aisha al Ba'uniyya, Aisha al Manubiya, Samiha Ayuverdi, Lala Zainab, and others. Late Sufi women left behind their works. Note that in the Mevlevi, Naqshbandi and Chishti orders, women have always been respected, women-sheikhs have met.

Thus, biographies of Sufi women can be found in the writings of early Muslim scholars. Consequently, Sufi women were among the first to accept the ascetic teaching, experienced mystical experience and gathered visitors around them. Throughout the centuries, women, like men, have continued to carry the light of love. For various reasons, women were often less visible than men, but nevertheless they were active participants in Sufi religious practice. In some Sufi circles, women participated in the practice with men, in other orders, women gathered in their circles and worshiped separately from men. Some women indulged in asceticism and withdrawal from society, others chose the active position of a benefactress and created educational circles.

\section{International Organization of Sufi Women}

The International Organization of Sufi Women (1993) is rightfully considered one of the most authoritative women's Sufi organizations. This organization is part of the non-governmental organizations of the United Nations (UN). It has its own organizational structure. The head and cofounder is Nahid Angha, a follower of Sufism, scholar, lecturer and human rights activist. She is the author of over twenty published books and numerous articles. As an expert, she lectured at the UN, UNESCO, in the Parliament of World Religions on the themes of Sufism, spirituality and human rights. One of the American international publications 
named her as one of 50 influential religious women leaders. She was educated in Iran, USA and UK. She holds PhDs in Psychology and Islamic Studies. Note that Nahid Angha is from an aristocratic family, his father is a Persian sheikh. Since the 1980s, she began her interfaith cooperation activities in the United States.

From 1994-2014, Nahid Angha annually organized a symposium on Sufism, which brought together Sufi schools and Sufi masters from all over the world. As a result, the history and biographies of over 140 Sufi masters and interfaith leaders have been published. She also organized the Festival of Song and Poetry of the Soul and Sacred Music in 2012, as well as the "Building Bridges of Understanding" event in 2014, highlighting the beauty of poetry and sacred music in spirituality and religious traditions [7].

In her work, Angha has focused on the social standard of gender roles in the Sufi religious context. Note that at the 1994 Sufi Symposium, Angha was the first Sufi woman to sit with male leaders in the central circle of dhikr, a position historically assigned to men, she led meditation and paved the way for other Muslim women to be active in Sufi society. In 1999, she hosted her first international conference, The Wisdom of Women, Women in Action. The participants were women leaders from different spiritual and cultural backgrounds. In 2004 and 2005, she organized a series of seminars and round tables on preventing domestic violence in California, as well as a series of round tables on intercultural studies of families in the Middle East who recently migrated to the United States. She also created the youth organization Voice for Justice, an interfaith and intercultural association that has received a special status in UNICEF.

Sufi women distinguish the following from their achievements: bringing the influence and leadership of Sufi women into traditional Sufi gatherings; taking an active and leading role in the global community through interfaith organizations; creation of a forum for the exchange of ideas, traditions and teachings among Sufi women from different orders and cultures, etc. Note that the Sufi Women's Organization is not the only organization uniting Sufi women, but is undoubtedly a global organization with a humanitarian and peacekeeping mission. In almost all existing Sufi orders, women play an important role in preserving, transmitting Sufi traditions and educating the new generation. New Sufi teachings are increasingly developing in the mainstream of syncretism, and women are actively involved in propaganda work.

Sufi educational institutions are currently developing. It should be noted that several Sufi educational institutions operate legally in America. One of these is the University of Spiritual Health and Sufism in California. The University of Sufism and Modern Sciences in Pakistan is based on the shrine of the Sufi saint Hazrat Shah Abdul Latif Bhittai [8]. Universities invite women scholars along with men as lecturers. There is no gender discrimination for those wishing to study.

\section{Women in Modern Sufi Tariqahs in Kazakhstan}

Several Sufi groups there are in Kazakhstan. Women are also followers of these groups.

In the Jahriya tariqah, who consider themselves the heirs of the tradition of H.A. Yasawi women practice loud dhikr. Women conduct dhikr in separate rooms. Researcher B. Babadzhanov conducted research in this tariqa. He notes that a special layer in the group is made up of girls and women who participate in rituals and gatherings. For some girls, this is a way of self-knowledge and familiarization with the ancient Kazakh culture, a way to overcome alienation in a big city and find a suitable team for communication. For other girls and women, this is the hope for healing from diseases. The head of the Sufi group, Sheikh Ismatulla Maksumov, proclaimed the possibility of healing through participation in Sufi rituals through a constant appeal to Allah for healing. There were separate women's madrasahs or women's circles. Agitators of the Sufi group actively conducted lectures and seminars in higher educational

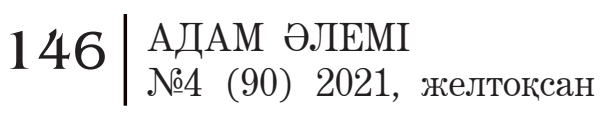


institutions, both boys and girls attended such events [9, p. 50-53].

Field studies conducted by the authors indicate that women are attracted as new adepts along with men. Currently, Sufi adepts are receiving foreign education in Turkey [10, p.115]. This helps to attract students from Kazakhstan and the former Soviet Union countries. Students are far from their homeland and family, and therefore they seek communication with compatriots. In this vein, the wives of Sufi ideologists play an important role, creating a trusting atmosphere and a warm welcome for newcomers, showing care. Some Sufi wives are actively promoting on social networks, posting videos with Sufi myths and legends, and advertising books and works of their husbands. Note that Sufi wives generally lead a secular lifestyle and do not wear religious clothing. In general, the attitude towards women in this Sufi community is positive. They treat women and girls with respect, promote the development of talents, and pay special attention to education and upbringing. Women can work, be creative, or devote themselves to raising children. There are no strict criteria for the number of children in Sufi families, while the community encourages large families. It should be noted that the study of foreign languages, the development of critical thinking, and memory training are strongly encouraged. It should be noted that this Sufi group has been present in Kazakhstan for about 20 years. Over the years, the role of women has not changed dramatically, but now, with the development of the Internet and social networks, women are playing an increasingly active missionary role.

Tariqah Naqshbandiya also has a centuries-old tradition in Kazakhstan. History contains information about famous Naqshbandi women. However, the extent to which women participate in it is not known for certain. After analyzing the official websites of the brotherhood abroad, we did not find individual events for women or women's circles. The photographs in official web-sites are mostly of men. On official YouTube channel of Kazakhstan's lider Kurbanali Ishan there are no video or picture of women, also there are no evidence of participation in meetings [11]. So, position of women or attitude to women in this group can be research in the future.

The Sufi tradition of Qadiriya exists on the territory of Kazakhstan. It originates from the period of deportation of the Chechen and Ingush people to Kazakhstan. Internally displaced persons were settled throughout the country. In the north of Kazakhstan, in the Akmola region in the village of Krasnaya Polyana, there are Chechens and Ingush who adhere to the Qadiriya tradition of VisKhodja. The loud dhikr helped them survive the hardships of deportation. A distinctive feature is the change in the criteria for admission to dhikr, namely, the permission to participate in dhikr for women together with men. According to the field data of the authors, the followers of this Sufi tradition rely on the Quran, namely, the admission to the religious practice of women and children. The Qadiriya's justify their actions by the fact that many people died as a result of the deportation, and every survivor had something to do with it. Of course, such innovations have become the subject of criticism from compatriots from the Chechen Republic. In general, the participation of women in dhikr is traditional for the Qadiriya tariqah. According to data from open information sources, women (mostly elderly or married) gather for dhikr in private homes, while accompanying men are waiting for them on the street. The movements and words are the same as during the male dhikr. Note that dhikr is mainly held during religious holidays and everyday events (weddings, funerals, etc.). During the interview, the head of the district told about occasion, in the early 2000 s, the council of elders banned the sale of alcohol due to the fact that young people insulted an adult woman. This is due to the existing tradition of respect for women in society [12, p. 115]. In general, the Chechens and Ingushs have different internal rules of conduct, including respect to women. For example, E. Isaev in his article "Respect for a Chechen woman" writes that there is an unwritten law: "If a woman is elder than you - she is like your mother, if she is on your age or younger, she is like your sister!».

https://adamalemijournal.com

ISSN 1999-5849 
In the house, wife is free from heavy and dangerous work, which allowed them to fully devote themselves to the family, raising children. In addition, it was considered indecent to speak loudly in the presence of a woman, and even more to swear and blackguard. In addition, the guilty person paid 7 cows for abusing a girl or a woman; for abusing a married woman, he lost 10 cows and was expelled from the community. The blood of two men was shed for the murdered woman. Moreover, members of the community did not cross the road for the old women, they waited until they passed. An interesting fact is that men came to a woman (elder) for advice, taking into account her life experience, knowledge of customs, ability to understand another, and a desire to help. [13]

After gaining independence, various Turkish Sufi groups began to appear in Kazakhstan. [14, p.130] This is due to the attraction of foreign investors and the development of international cooperation. Turkish businessmen, in addition to sales offices, began to open educational institutions, thereby spreading their ideas to the younger generation. Kazakh-Turkish lyceums functioned in various regions of the country. At first, only young men studied in boarding schools, then departments for gifted girls began to open. Note that Turkish educational institutions were also opened in other CIS countries. However, for their illegal activities, some Sufi groups are legally banned in Russia and Uzbekistan. Thanks to field observations of the activities of women's educational circles in Turkey, it can be concluded that Turkish women's Sufi branches are actively functioning in Kazakhstan. Citizens of Turkey move to Kazakhstan with their families and will naturally look for compatriots far from their homeland. Researchers of Turkish tariqas note the strict organizational structure of Sufi groups, outsiders are not allowed to attend meetings, and group members cannot refuse internal assignments. In this regard, there are difficulties in studying the activities of these Sufi groups.

One of youngest tariqah in Kazakhstan is the Sufi group "Sukhba», the leader is Murat Hakim. In fact, the sheikh began his activities in 2015. However, he currently does not have a legitimate basis (sil-sila) for his leadership. Moreover, of all the leaders of Kazakhstani Sufi groups, he is the most educated, namely, a graduate of the Egyptian University of Al-Azhar. According to the author's field research, women play an active role in this Sufi group. There is a women's circle headed by a woman named Amina. She has an authoritative position in the group. She is entrusted with part of the responsibilities for the leadership of the tariqah. Women in tariqah are full members of the community. Take part in meetings. However, due to the recent appearance of this group in Kazakhstan, its activities require further academic study.

The next young Sufi community in north Kazakhstan is Kenesary Sarbazdary with leader Ergali Kopeev. The Sufi group is located in the northern region of the country city - Petropavlovsk. According to the expert, O.V.Sinyakov in the region, more than half of the inhabitants are Christiansy. [15] Leader Ergali Kopeev identifies himself with the Shaziliya tariqa, considers himself a follower of the Egyptian sheikh Yusri Rushti. This is probably due to the fact that his exwife is a Chechen. In the Caucasian region of the Russian Federation, the Shaziliya tariqah has an old tradition. Also, E. Kopeev, to prove his legitimacy, points out that he is a descendant of the saint (auliya) of this region. In 2016, the group registered a YouTube channel, where the leader's video messages are systematically published. In general, the views of this Sufi group are aimed at uniting the Turkic peoples, reviving the Turan army, that is, pan-Turkic. In his videos, the head of the Sufi group expresses his opinion about women. Thus, recent videos by E. Kopeev are related to current news about women. In one news, the Sufi leader ridicules the act of Kazakh women who shaved their hair in protest of the current political authorities in Kazakhstan and in solidarity with the opposition [16]. This caused indignation in E. Kopeev, he cited the paraphrase that women have long hair, but a short mind. He called this act of women is silly. It is worth noting that in the comments, the followers supported $\mathrm{E}$. Kopeev. In another video dated November 
3, 2020, the news from the Internet portal was discussed, where the female leader of the Sufi group Nurjilar in the Republic of Tatarstan addressed the Head of Turkey R.T. Erdogan for help in connection with the persecution of the community by the Russian authorities [17]. Also, in another video, E. Kopeev supported the woman's act, where she committed hooligan actions against not Kazakh-man. [18] These actions in $\mathrm{E}$. Kopeev caused a positive reaction and a positive assessment. He recognized patriotic that illegal action. At all videos in official YouTube channel there is disclaimer «we do not try to impose our will on anyone or offend, we only share our opinion and vision of a particular situation». However, at present, the authors of article do not know for certain whether there are women in this Sufi group, what position they occupy. These issues require further academic study.

Thus, female Sufis in Kazakhstani orders are active followers. Mostly female Sufis are educated. They construct their identity through self-reflection. Women change the criteria of religious practice and thus become active actors. Sufi women independently enter tariqah, consciously choosing their own path. Kazakhstani tariqas follow the jilveti line (American model), that is, they choose an active position in society. Note that an increase in the number of Sufi groups can lead to social fragmentation according to confessional affiliation. In addition, the opinion of official Islam regarding the activities of Sufi groups in the country is negative. However, the opinions of scholars differ, some scholars believe that the religious diversity in the country is positive, while others consider modern Sufi groups to be pseudo-Sufi and focus on the negative aspects of their activities.

\section{Results}

The historically formed tradition of Yassaviya and Naqshbandiya in the country has changed in recent years [19, $p$. 67-68]. The dynamics of the development of Sufism in Kazakhstan evident about positive growth $[20$, p. 226]. Appear new Sufi groups, leaders are changing traditional discourses, new religious constructs are emerging. At the present stage, the legitimization of the powers of the leader of the Sufi group does not require strict regulation and confirmation of sil-sila. New Sufi communities have different goals for their teachings, but they overlap. Thus, the common ideas are the consolidation of the Turkic peoples, the revival of the traditions of the Kazakh people, Kazakhstan's patriotism, etc. [21, p. 97]. Thus, there is religious diversity and interconfessional dialogue in Kazakhstan.

The development of Internet communications, social networks and instant messengers has had an impact on religious groups around the world. Preaching, campaigning and advertising have become more accessible and larger. Modern Kazakhstani Sufi groups actively use different methods of spreading their teachings, in particular women. For Sufism, women's participation is natural. Women stood at the origins of Sufism, were vivid examples of asceticism and the concept of halveti (departure from the mundane). We have considered several historical figures of Sufi women, but it should be noted that objectively there may be more of them. Sources written by female Sufis are poorly understood. Some of the stories of Sufism and the place of women in Sufism are ignored among modern Muslims. Many famous sheikhs and Muslim scholars had female teachers, students, and spiritual friends who greatly influenced their worldview. And wives and mothers provided support to their family members, continuing their own Sufi path. For the most part, the words of women in Sufism that remain from past centuries are taken from traditional descriptions of their commentaries or from the poems that developed around their words. Although the Quran strongly encourages education for both women and men, women sometimes receive fewer opportunities to study than men in similar circumstances. Another important aspect is the representation of the image of religious, practicing women in the media as oppressed and submissive. It is important to objectively represent the personalities of women, eliminating stereotypes that have developed in society.

$$
\begin{array}{r|r}
\text { https://adamalemijournal.com } & \mathbf{1 4 9} \\
\text { ISSN 1999-5849 } & \mathbf{1}
\end{array}
$$


Temirbayeva A., Temirbayev T., Tyshkhan K., Kamarova R.

\section{Conclusion}

In modern times, women are fullfledged religious leaders, head Sufi organizations, and fight to empower and narrow the gender gap. In Kazakhstan tariqas, women play an active role both socially and in attracting new adherents. Taking into account the statistics, the majority of religious women in Kazakhstan are the leaders of their own business, where they make a significant contribution to the country's gross domestic product. The access to education and education of women testifies to their free choice. Syncretism of the intellectual direction with psychological techniques is gaining popularity in the country. Women create new religious constructs, self-identification comes to the fore, self-reflection of women in tariqas becomes relevant. Nowadays, in Kazakhstan, there is a Sufi sheikh woman Svetlana, who gained sil-sila from Pakistan teachers like Osho. In addition, in our country came Sufi sheikh woman Firdousa (follower of Osho teaching) from Kyrgyzstan. All of them have own auditory, followers and supporters. Undoubtedly, the activities of female Sufi movements in Kazakhstan require further academic study.

In conclusion, we note that women have played an important role in the development of art, science, education, entertainment, politics and much more, but the sphere of religion remains one of the most difficult for women's leadership. Contemporary gender research focuses on women's agency, changing conceptual approaches to understanding women's agency. Women, through their efforts and perseverance, contribute to equality and freedom in the field of religion and spirituality.

\section{References}

1 Абдрахманова А.К. Роль женщины в казахском традиционно обществе. / Матер. междунар. научн. конф. «Роль женщины в развитии современной науки и образования». - Минск: Белорусский государственный университет, 2016. - С. 250-253.

2 Chepeleva A.V. Zhenshchiny $v$ sufizme. Eticheskiy aspekt filosofii lyubvi: avtoref. k.f.n.: 09.00.05 / Sankt-Peterburgskiy gosudarstvennyy universitet. - SPb, 2016. - $15 \mathrm{~s}$.

3 Mahmood, Saba. Politics of Piety. The Islamic Revival and the Feminist Subject - 2005. - C. 216-245.

4 Avishai, Orit. «Doing Religion» in a Secular World. Women in Conservative Religions and the Question of Agency. / University of California. Berkeley. Gender and Society. - 2008. - C. 12-38.

5 Коран. Перевод и комментарии И. Ю. Крачковского. Под редакцией В.И. Беляева (Предисловия В.И. Беляева иП. А. Грязневича). Изд. 2-е. - М.: «Наука», 1986. - С. 727.

6 Кныш А.Д. Мусульманский мистицизм: краткая история / А. Д. Кныш; пер. с англ. М. Г. Романов. - СПб.: «Издательство «ДИЛЯ», 2004. -464 c.

7. International Association of Sufism. [Электронный ресурc] URL http://ias.org/ buildingbridges/ (дата обращения: 24.04.2020).

8 University of Sufism and Modern Sciences. [Электронный ресурc] URL https://www.usms. edu.pk/ (дата обращения: 09.04.2020).

9 Собрание фетв по обоснованию зикра джахр и сама' / Сост.: Б.М. Бабаджанов, С.А. Мухаммадаминов; отв. ред. А.К. Муминов Алматы: Дайк-Пресс, 2008. - С. 312.

10 Темирбаева А., Смагулов М., Темирбаев

т. Суфийские образовательные практики в современном Казахстане: прошлое и настоящее / Адам әлемі. - Алматы, 2019. № 4 (82) - С. 112-117.

11 Официальный YouTube канал Хазіреті Құрбанәлі Ахмед ишан [Электронный ресурс] URL https://cutt.ly/ggDqhOc (дата обращения: 04.11.2020).

12 Этнокультурные центры Ассамблеи народа Казахстана: взаимодействие этнического и религиозного в светском обществе: монография / Д.Н.Нурманбетова, Р.И.Камарова, Т.А.Липина, К.Тышхан, Ю.В.Шаповал, А.Ю.Антипин, Г.Т.Камарова, Г.Ш.Асылбекова. - Астана: ТОО «Мастер По», 2017. - 197 c.

13 Исаев Э. Уважение к чеченской женщине / [Электронный ресурс] URL https:// nohchalla.com/obychai-i-tradicii/859-uvajeniek-chechenskoy-jenshine (дата обращения: 04.11.2020).

14 Темирбаева А. Новые религиозные конструкты суфийских практик в Казахстане. / Матер. межд.науч.конф. «EurasiaScience». Москва, 2017. - С.129-130.

15 Синяков О.В. Об информационноразъяснительной работе в сфере религии в Северо-Казахстанской области. / Материалы онлайн круглого стола 29.10.2020. [Электронный ресурс] URL http://religionscongress.org/ru/news/novosti/567 (дата 
обращения: 04.11.2020).

16 Про лысого Аблязова и лысых глупых женщин [Электронный ресурc] URL https:// www.youtube.com/watch?v=Ary8IL1jPBw\&feat ure=youtu.be (дата обращения: 04.11.2020).

17 В Татарстане призывают Эрдогана защитить мусульман от властей РФ [Электронный ресурс] URL https://www. youtube.com/watch?v=4NOMHVBJLQs\&featur e=youtu.be (дата обращения: 04.11.2020).

18 Все-таки жив в казашках дух воина! [Электронный ресурc] URL https://www. youtube.com/watch?v=ZvjcN0A4F6s\&feature $=y$ outu.be (дата обращения 04.11.2020).

19 Смагулов М.Н., Досмаганбетова А.А., Сейтахметова Н.Л., Сартаева Р.С., Сагикызы А. Институализация исламского образования в казахстанском секулярном обществе / Европейский журнал науки и теологии. - 2018, №14. - С. 65-75.

20 Молдагалиев Б.Е., Смагулов М., Сатершинов Б.М., Сагикызы А. Синтез традиционных и исламских ценностей в Казахстане. / Европейский журнал науки и теологии. - 2015, № 5. - С. 217-229.

21 Темирбаева, А. и др. (2021) Суфийские практики в современном Казахстане: традиции и новации, Центральная Азия и Кавказ. Volume 24, Issue 1. - 91-98. DOI: https:// doi.org/10.37178/ca-c.21.1.08

\section{Transliteration}

1 Abdrakhmanova A.K. Rol' zhenshchiny v kazakhskom traditsionno obshchestve. // Mater. mezhdunar. nauchn. konf. "Rol' zhenshchiny $\checkmark$ razvitii sovremennoy nauki i obrazovaniya»Minsk: Belorusskiy gosudarstvennyy universitet, 2016. - S. 250-253.

2 Chepeleva A.V. Zhenshchiny $v$ sufizme. Eticheskiy aspekt filosofii lyubvi. // Avtoreferat dissertatsii na soiskaniye uchenoy stepeni kandidata filosofskikh nauk. // SanktPeterburgskiy gosudarstvennyy universitet. 2016. - S. 15.

3 Saba Mahmood. Politics of Piety // The Islamic Revival and the Feminist Subject. - 2005. - S. 216-245.

4 Avishai, Orit. «Doing Religion» in a Secular World. Women in Conservative Religions and the Question of Agency. // University of California. Berkeley. Gender and Society. - 2008. - C. 12-38.

5 Koran. Perevod i kommentarii I. YU. Krachkovskogo. // Pod redaktsiyey V.I. Belyayeva (Predisloviya V. I. Belyayeva i P. A. Gryaznevicha). Izd. 2-ye. M. Glavnaya redaktsiya vostochnoy literatury izdatel'stva «Nauka». - 1986. - S. 727.

6 Knysh A.D. Musul'manskiy mistitsizm: kratkaya istoriya / A. D. Knysh; per. s angl. M. G. Romanov. - SPb.: «Izdatel'stvo «DILYA», 2004. $464 \mathrm{~s}$.

7 International Association of Sufism. [Elektronnyy resurs] URL http://ias.org/ buildingbridges/ (24.04.2020).

8 University of Sufism and modern sciences. [Elektronnyy resurs] URL https://www.usms.edu. pk/ (09.04.2020).

9 Sobraniye fetv po obosnovaniyu zikra dzhakhr i sama'. // Sost.: B.M. Babadzhanov, S.A. Mukhammadaminov; otv. red. A.K. Muminov. Dayk-Press. Almaty. - 2008. - S. 312.

10 Temirbayeva A., Smagulov M., Temirbayev T. Sufiyskiye obrazovatel'nyye praktiki $V$ sovremennom Kazakhstane: proshloye i nastoyashcheye / Adam əlemí № 4 (82) - Almaty, 2019 - S.112-117.

11 Ofitsial'nyy YouTube kanal Khazireti Kurbanali Akhmed ishan [Elektronnyy resurs] URL https://cutt.ly/ggDqhOc (04.11.2020).

12 Etnokul'turnyye tsentry Assamblei naroda Kazakhstana: vzaimodeystviye etnicheskogo i religioznogo $v$ svetskom obshchestve: monografiya / D.N.Nurmanbetova, R.I.Kamarova, T.A.Lipina, K.Tyshkhan, YU.V.Shapoval, A.YU. Antipin, G.T.Kamarova, G.SH.Asylbekova. Astana: TOO «Master Po», 2017. - 197 s.

13 Isayev E. Uvazheniye $k$ chechenskoy zhenshchine. // [Elektronnyy resurs] URL https:// nohchalla.com/obychai-i-tradicii/859-uvajeniek-chechenskoy-jenshine (04.11.2020).

14 Temirbayeva A. Novyye religioznyye konstrukty sufiyskikh praktik v Kazakhstane. / Mater. mezhd.nauch.konf. «EurasiaScience». Moskva, 2017. - S.129-130.

15 Sinyakov O.V. Ob informatsionnoraz"yasnitel'noy rabote $v$ sfere religii v SeveroKazakhstanskoy oblasti. // Materialy onlayn kruglogo stola 29.10.2020. [Elektronnyy resurs] URL http://religions-congress.org/ru/news/ novosti/567 (04.11.2020).

16 Pro lysogo Ablyazova i lysykh glupykh zhenshchin [Elektronnyy resurs] URL https:// www.youtube.com/watch?v=Ary8IL1jPBw\&feat ure=youtu.be (04.11.2020).

$17 \mathrm{~V}$ Tatarstane prizyvayut Erdogana zashchitit' musul'man ot vlastey RF [Elektronnyy resurs] URL https://www.youtube.com/watch?v= 4NOMHVBJLQs\&feature=youtu.be (04.11.2020).

18 Vse taki zhiv v kazashkakh - dukh voina! [Elektronnyy resurs] URL https://www.youtube. $\mathrm{com} /$ watch?v=ZvjcN0A4F6s\&feature=youtu.be (04.11.2020).

19 Smagulov M.N., Dosmaganbetova A.A., Seytakhmetova N.L., Sartayeva R.S., Sagikyzy A. Institualizatsiya islamskogo obrazovaniya v kazakhstanskom sekulyarnom obshchestve 
/ Yevropeyskiy zhurnal nauki i teologii. - 2018, №14. - S. 65-75.

20. Moldagaliyev B.Ye., Smagulov M., Satershinov B.M., Sagikyzy A. Sintez traditsionnykh i islamskikh tsennostey $\mathrm{v}$ Kazakhstane. / Yevropeyskiy zhurnal nauki i teologii. - 2015, № 5. - S. 217-229.

21. Temirbayeva, A. et al. (2021) Sufi practices in modern Kazakhstan: traditions and innovations, Central Asia and the Caucasus. Volume 24, Issue 1. - 91-98.

\section{INFORMATION ABOUT AUTHORS}

\section{Aigerim Temirbayeva}

Talgat Temirbayev

Kenshilik Tyshkhan

Ruziya Kamarova

Айгерім Алматқызы Темірбаева

Талғат Тулюбайұлы Темірбаев

Кеңшілік Тышхан

Рузия Исламқызы Камарова

Айгерим Алматкызы Темирбаева

Талгат Тулюбаевич Темирбаев

Кеншилик Тышхан

Рузия Исламовна Камарова
PhD student, L.N. Gumilyov Eurasian National University, Nur-Sultan, Kazakhstan

PhD, N.Nazarbayev Center for Development of Interfaith and Intercivilization Dialogue, Nur-Sultan, Kazakhstan

Candidate of Philosophycal Sciences, Docent, L.N. Gumilyov Eurasian National university, Nur-Sultan, Kazakhstan

Candidate of Philosophycal Sciences, Docent, N.Nazarbayev Center for Development of Interfaith and Intercivilization Dialogue, Nur-Sultan, Kazakhstan

PhD докторант, Л.Н. Гумилев атындағы Еуразия ұлттық университеті, Нұр-Сұлтан, Қазақстан

$\mathrm{PhD}$, Конфессияаралық және өркениетаралық диалогты дамыту жөніндегі Н. Назарбаев орталығы, Нұр-Сұлтан, Қазақстан

Философия ғылымдарының кандидаты, доцент, Л.Н.Гумилев атындағы Еуразия ұлттық университеті, НұрСұлтан, Қазақстан

Философия ғылымдарының кандидаты, доцент, Конфессияаралық және өркениетаралық диалогты дамыту жөніндегі Н. Назарбаев орталығы, Нұр-Сұлтан, Қазақстан

$\mathrm{PhD}$ докторант, Евразийский национальный университет им. Л.Н. Гумилева, Нур-Султан, Казахстан

$\mathrm{PhD}$, Центр H. Назарбаева по развитию межконфессионального и межцивилизационного диалога, Нур-Султан, Казахстан

Кандидат философских наук, доцент, Евразийский национальный университет имени Л.Н. Гумилева, НурСултан, Казахстан

Кандидат философских наук, доцент, Центр Н.Назарбаева по развитию межконфессионального и межцивилизационного диалога, Нур-Султан, Казахстан 